Тєнєшев В., Котис В.

Нетрадиційні способи доказування злочинів, чи $€$ перспектива?

DOI:

УДК 343

\title{
Владислав Тєнєшев,
}

викладач кафедри міжнародного права $i$

міграційної політики юридичного факультету

Тернопільського начіонального

економічного університету

ORCID: https://orcid.org/0000-0001-7631-1778

\section{Віка Котис,}

студентка II курсу юридичного факультету Тернопільського начіонального економічного університету

\section{НЕТРАДИЦІЙНІ СПОСОБИ ДОКАЗУВАННЯ ЗЛОЧИНІВ, ЧИ С ПЕРСПЕКТИВА?}

У статті досліджено перспективу використання таких нетрадиційних способів доказування злочинів в Україні як поліграф, гіпноз, ясновидіння та телепатія. Проаналізовано досвід іноземних держав, умови застосування, загальні рекомендації щзодо використання досліджуваних методів у кримінальному судочинстві. Вивчено необхідність законодавчого регулювання нетрадиційних способів доказування злочинів в України.

Ключові слова: злочин,кримінальний прочес, нетрадчиійні способи доказування злочинів, поліграф, гіпноз, екстрасенсорика, ясновидіння, телепатія.

Тенешев В., Котис В.

Нетрадиционные способы доказывания преступлений, есть ли перспектива?

В статье исследовано перспективу использования таких нетрадиционных способов доказывания преступлений в Украине как полиграф, гипноз, ясновидение и телепатия. Проанализирован опыт иностранных государств, условия применения, общие рекомендаџии по использованию исследуемых методов в уголовном судопроизводстве. Изучено необходимость законодательного регулирования нетрадиционных способов доказывания преступлений в Украине.

Ключевые слова: преступление, уголовный прочесс, нетрадиционные способы доказывания преступлений, полиграф, гипноз, экстрасенсорика, ясновидение, телепатия.

Tienieshev V., Kotys $V$.

Unconventional ways of proving crimes, is there a prospect?

The development of mankind is rapidly rising in spirals of time and space, yesterday unknown today becomes a clear everyday life. In the future, total digital control over society will make it possible to decriminalize human relations, and the inevitability of punishment will become mandatory. It is clear that crimes, in turn, will also mutate to get around the law again and again. There is endless competition between proving crimes and opportunities to avoid punishment. In this age-old pursuit, the rule of law often suffers, and, as a consequence, justice also suffers.

A necessary element of the legal procedure is the requirement of speed of criminal proceedings, as indicated by the basic international documents. Thus, according to Article 14 (3) of the International Covenant on Civil and Political Rights, "everyone has the right to a court to hear his case without undue delay". And in of Article 28 (5) of the Criminal Procedure Code of Ukraine states: "Everyone has the right to have charges brought against him as soon as possible or to be brought to trial or to have the relevant criminal proceedings closed." To ensure the speed of the criminal process, the question of using unconventional methods of proving crimes, which will undoubtedly help in this, is of interest.

The article explores the prospect of using such unconventional methods of proving crimes in Ukraine as polygraph, hypnosis, clairvoyance and telepathy. The experience of foreign states, conditions of application, general recommendations on the use of investigated methods in criminal proceedings are analyzed. The necessity of legislative regulation of unconventional ways of proving crimes in Ukraine is studied.

Keywords: crime, criminal process, unconventional ways of proving crimes, polygraph, hypnosis, psychics, clairvoyance, telepathy.

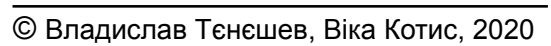


Кримінальне право та кримінологія. Кримінально-виконавче право. Кримінальний процес та криміналістика. Судова експертиза. Оперативно-розшукова діяльність. Судоустрій. Прокуратура та адвокатура.

Постановка проблеми. Розвиток людства стрімко піднімається спіралями часу і простору, вчора невідоме сьогодні стає зрозумілою буденністю. Можливо, у майбутньому тотальний цифровий контроль за суспільством дозволить декриміналізувати відносини між людьми, а невідворотність покарання стане обов'язковим. Зрозуміло, що злочини, у свою чергу, також мутуватимуть, щоб знову і знову обійти закон. Існує нескінченне змагання між доказуванням злочинів і можливостями уникнути покарання. У цій одвічній гонитві часто страждає принцип верховенства права, а як наслідок, - страждає і справедливість.

Необхідною складовою правової процедури є вимога швидкості кримінального провадження, на яку вказують основоположні міжнародні документи. Так, згідно ч. 3 ст. 14 Міжнародного пакту про громадянські і політичні права «кожен має право на розгляд його справи судом без невиправданої затримки»[1]. А у ч. 5 ст. 28 КПК України вказано: «Кожен має право, щоб обвинувачення щодо нього в найкоротший строк або стало предметом судового розгляду, або щоб відповідне кримінальне провадження щодо нього було закрите»[2]. Для забезпечення швидкості кримінального процесу становить інтерес питання щодо використання нетрадиційних способів доведення злочинів, які, безперечно, зможуть у цьому допомогти.

Аналіз останніх досліджень і публікацій. Тема використання нетрадиційних методів доведення злочинів досі залишається актуальною для обговорень та досліджень. Проблема допустимості доказів, отриманих шляхом використання певних видів нетрадиційних методів доведення злочинів, досліджувалась такими науковцями: Е. П. Іщенко, Р. С. Бєлкін, Т. А. Седова, В. К. Веселицький, Н. І. Клименко, Д. А. Мовчан, В. Ю. Калугін, Т. В. Авер'янова, С. О. Книженко тощо.

Метою статті є дослідження перспективи використання нетрадиційних методів доведення злочинів в Україні та аналіз досвіду іноземних держав.

Виклад основного матеріалу дослідження. Криміналістиці відомі такі нетрадиційні методи розслідування злочинів: поліграф, гіпноз, екстрасенсорика, телепатія. Ці методи слід поділити на дві групи:

- методи, які не пов'язані з безпосереднім контактом з опитуваною особою (екстрасенсорика, телепатія, ясновидіння);

- методи, які пов'язані з отриманням інформації шляхом безпосереднього контакту з опитуваною особою (гіпноз, поліграф).

Недоліком їх застосування є те, що відомості, які отримані нетрадиційним способом, не завжди можуть бути визнаними як джерело доказів, а лише, як джерело оперативної інформації. Відповідно до законодавства США, федеральні суди на свій розсуд можуть використовувати цю інформацію як доказ. Такі штати, як Каліфорнія, Арізона, Невада, Джорджія та Флорида визнають інформацію, отриману нетрадиційними способами, як доказ, якщо прокурор і підозрюваний погоджуються визнати її правдивою. У Сінгапурі ці методи найчастіше використовуються як засіб допиту або отримання пошукової інформації, але можуть використовуватися і як доказ в тому випадку, коли відомості будуть перевірені психологом під час судового розгляду. У Німеччині суддям забороняється свобода прийняття рішень та винесення вироку, залучаючи лише інформацію, отриману шляхом використання нетрадиційних способів доведення. Парламент Ізраїлю у 2005 році законом «Про використання поліграфа» визнав застосування нетрадиційних методів неприйнятними в кримінальному праві, проте вони часто застосовуються як докази у цивільному суді або як метод перевірки людей під час влаштування на роботу. Відповідно до законодавства Індії, цю інформацію часто використовують як доказ у тому випадку, коли перевірка проводилася цивільною особою, а не співробітником поліції чи працівником суду.

Одним із найпоширеніших нетрадиційних методів є поліграф, який ще називають детектором брехні. Поліграф - це пристрій, що призначений для одночасної реєстрації частоти серцебиття, тиску, дихання, температури тіла під час тестування та за допомогою якого можна визначити, коли особа говорить неправду. Дієвість поліграфа науково доведена та обгрунтована, адже реакції організму в цілому не піддаються свідомому контролю людини.

Україна на офіційному рівні визнає поліграфічні дослідження, як один із методів перевірки людей, зокрема під час працевлаштування на роботу нових співробітників у силові структури. Та чи доцільно використовувати поліграф в кримінальних провадженнях? Вже не перший рік йде обговорення стосовно цієї теми, однак жодних зрушень, окрім запропонованого законопроєкту № 3611 від 10.12.2015 р. «Про доповнення Кримінального процесуального кодексу України положеннями щодо використання поліграфа» [3], що 29.08.2019 був відкликаний Верховною Радою України, не було помічено. Рішення аргументується тим, що під час використання цього методу, виникає суперечливість між Конституцією України (ст. 28) та Кримінальним Кодексом України (ст. 385). У ст. 28 Конституції України передбачено право людини на відмову від будь-якого дослідження щодо неї [4], водночас ст. 385 Кримінального Кодексу України встановлює 
Тєнєшев В., Котис В.

Нетрадиційні способи доказування злочинів, чи $€$ перспектива?

відповідальність за відмову від надання показань [5]. Тому, перш ніж використовувати поліграф, потрібно нормативно врегулювати суперечності щодо такого тестування.

За офіційними даними, поліграф використовується в 57 країнах світу. У Бельгії перші поліграфні обстеження були проведені у 1997 році. Саме тоді на території держави діяв серійний вбивця дітей Марк Дютру, для викриття якого вищим керівництвом держави було прийнято рішення використати методику поліграфного опитування. У результаті роботи поліграфологів слідчі отримали орієнтовну інформацію, яка дозволила знайти, у тому числі, тіла вбитих дітей. Також відомо, що один із російських агентів, ексспівробітник ЦРУ Гарольд Ніколсон, який за шпигунство відбуває 25-річний термін покарання у США, був перевірений на чесність за допомогою поліграфа. Було виявлено, що він збирає і передає таємну інформацію представникам спецслужб іншої держави. Перевірка його банківських рахунків, обшук квартири, негласне зняття інформації з його домашнього комп’ютера підтвердили підозри.

В Україні також були випадки, коли поліграф застусовувався та успішно допомагав вивести на «чисту воду» бажаючих заробити на брехні. У 2011 році до Могилева-Подільського районного відділу міліції Вінницької області, звернувся 38-річний громадянин Молдови. Він разом із дружиною останнім часом працював в Італії. Там подружжя придбало автомобіль Тоуota, на якому їхали до родичів у Київ. Коли подружжя перетнуло кордон, на території міста чоловікові стало погано. Він разом із дружиною звернувся по допомогу до лікарні. Доки хворого обстежували, дорогу іномарку,залишену поблизу лікувального закладу, викрали. Орієнтування на викрадену автівку було розіслано усім екіпажам ДАІ області, проводилися розшукові заходи. Однак згодом з'ясувалося, що іномарку було придбано в Італії у кредит і застраховано. Власник сплатив лише частину вартості машини, а у разі викрадення автомобіля страхова компанія мала компенсувати повну іiі ціну. Підозри міліції у правдивості заявника підтвердив поліграф, який постановив «діагноз» потерпілому - брехня.

Отже, використання поліграфа у кримінальному розслідуванні сприятиме його пришвидшенню та допоможе значно спростити роботу органів досудового розслідування. Але такі тестування у доведенні злочинів повинні виконуватися лише в суворих рамках і з обов'язковим дотриманням правил, які зафіксовані в Законі «Про оперативно-розшукову діяльність» [6], Законі «Про судову експертизу» [7] та Постанові Кабінету Міністрів України Про затвердження Порядку проведення психофізіологічного дослідження із застосуванням поліграфа у Державному бюро розслідувань[8]:

- добровільна згода суб’єкта дослідження (відмова від проходження такої експертизи з використанням поліграфа не є підставою для визнання особи винною, однак цю інформацію фіксують у протоколі слідчої дії);

- свідома відмова підозрюваного від прав, наданих ст. 28 Конституції України[4];

- сертифікація цієї діяльності (проводити тестування повинен не працівник правоохорониих органів, а поліграфолог - особа, яка пройшла навчання в закладі освіти, що має відповідну ліцензію та отримала документ про освіту (диплом/свідоцтво) державного зразка. Поліграфолог повинен володіти мінімальною інформацією про злочин і не повинен мати приватного інтересу у цій справі. Ця особа має здійснювати свою діяльність за спеціальними методиками, встановленими у 2015 році членами Всеукраїнської асоціації поліграфологів);

- обов’язкове медичне обстеження суб'єкта перед дослідженням та перевірка наявності в його організмі медикаментозних засобів, наприклад заспокійливого. (За наявності певних хвороб дослідження не може бути проведене. Перелік хвороб вказаний у документі під назвою «Методика проведення психофізіологічних досліджень із застосуванням поліграфа» [9]);

- обов'язкова відео- та аудіофіксація. (До кадру відео повинна потрапляти і особа, яку перевіряють і поліграфолог).

Вважається, що розкриття інформації, що приховується із застосуванням поліграфа, почалося в 1895 році, коли італійський криміналіст Чезаре Ломброзо в роботі «Злочинна людина» [10] привів практику застосування приладу для виявлення брехні грабіжника. Та на сьогоднішній день, безумовно, світовим лідером із використання поліграфа є США.

В Україні є лише один виробник поліграфів, обладнання якого відповідає Державним стандартам України, - «Рубікон», ціна якого становить 3000 - 3500 доларів США. Навчання поліграфологів в Україні офіційно відбувається в Академії Служби безпеки України та у Всеукраїнській асоціації поліграфологів, які видають посвідчення на 3 роки. Вартість навчання становить 2000-5000 доларів США. На сьогоднішній день в Україні налічується близько 400 сертифікованих поліграфологів. 
Кримінальне право та кримінологія. Кримінально-виконавче право. Кримінальний процес та криміналістика. Судова експертиза. Оперативно-розшукова діяльність. Судоустрій. Прокуратура та адвокатура.

Ще одним нетрадиційним способом доведення злочинів, який активно використовується, є гіпноз. Метою використання цього методу в кримінальному провадженні є введення допитуваного суб'єкта в такий стан, при якому він знову «переживає» раніше сприйняту подію, тобто переноситься у певний період минулого часу для уточнення та активізації в пам'яті забутих ним важливих обставин кримінальної події.

У своїй практиці гіпноз використовують такі розвинені країни, а саме: Англія, Канада, Ізраїль, Австралія. Проте найбільшого поширення гіпноз набув у США. Він був використаний при розслідуванні справи Теодора Банді, який протягом 70-их років XX ст, за офіційними даними, згвалтував та вбив більше 36 жінок. Один із свідків, що бачив вбивцю, але не встиг його добре розгледіти, був введений у стан гіпнозу та безпомилково вказав на фото вбивці серед багатьох інших. Вже через декілька років Теодор Банді був засуджений до сметної кари за допомогою електричного стільця.

Також гіпноз допоміг у розкритті справи стосовно Альберта Десалво, відомого як Бостонський душитель, який вчиняв злочини в 1962-1964 роках. Під гіпнозом він описав вбивство Евелін Корбін, яке відбулось 8 вересня 1963 року, пригадавши подробиці, які вона називала тільки при розмові з ним, у тому числі щодо її здоров’я. Злочинця було засуджено до довічного позбавлення волі.

Сучасне законодавство України не містить жодного нормативно-правого акту, який би регулював застосування гіпнозу під час розслідування злочинів. Дискусійним є питання стосовно застосування гіпнозу під час допиту потерпілого і свідків, адже гіпноз є «вторгненням» гіпнотизера в людську свідомість та активний вплив на неї. При цьому неприпустимим є порушення конституційних прав особи, обман, фальсифікація, приниження людської гідності, ущемлення законних прав та інтересів і психологічне насильство. Багато українських науковців стверджують, що некомпетентність, поспіх та необізнаність правоохоронних органів у деяких питаннях, та зокрема і в галузі судового гіпнозу, робить цю процедуру просто небезпечною для здоров 'я опитаного.

Тому, гіпноз, як метод для розкриття злочинів, повинен застосовуватися в чітких рамках закону і за чіткими правилами:

- добровільність процедури, яка фіксується письмовою згодою особи;

- серифікація діяльності експерта, що підтверджена відповідними документами;

- відеофіксація процедури;

- ретельна перевірка фізичного та психологічного стану того, хто буде допитаний (проведення необхідних аналізів);

- застосування процедури у рамках положень закону, що забороняє використання обману, фальсифікації, приниження честі та гідності особи;

- заборона шантажу, погроз, обману, необгрунтованих обіцянок;

- максимальне обмеження в інформації гіпнотизера, що гарантуватиме його неупередженість.

Але навіть за дотриманням всіх умов слід враховувати, що дані, отримані цим способом, повинні базуватись на фактичних матеріалах, підлягати надзвичайно ретельній перевірці.

Також до нетрадиційного способу розкриття злочинів відносять екстрасенсорику. Екстрасенсорика - це це специфічна форма сприйняття людиною, наділеною високою чутливістю, за допомогою використання невідомих органів чуття та маловивчених механізмів сприйняття, що виходять за рамки п'яти загальновідомих - слух, зір, дотик, нюх, вестибулярний апарат. До неї зараховуються телепатія (передача інформації від мозку до мозку без посередництва чуттєвих каналів) та ясновидіння (здатність передбачити стани матеріальних явищ без умовиводів на основі відомих фактів).

Такий нетрадиційний метод як екстрасенсорика в основному використовується з метою отримання пошукової інформації, а саме: особи злочинця, його місце знаходження, причетність до злочину, місцезнаходження жертв та ошуканих осіб, спосіб та обстановку вчинення злочину.

Офіційно в Україні цей спосіб не регулюється жодним нормативно-правовим актом, але фактично використовується. Він був використаний у розслідуванні справи про вбивство вагітної жінки Світлани Грабко у Запоріжжі у 2014 році. Правоохоронці не могли знайти підозрюваного впродовж року, але злочин допомогли розкрити екстрасенси, які повністю відтворили обставини злочину та вказали на злочинця, його ім 'я, вік та де саме потрібно шукати тіло. Мертву жінку знайшли саме там, де вказали екстрасенси, до того як їі безуспішно шукали правоохоронні органи протягом цілого року. Через деякий час була доведена причетність обвинуваченого Олега Михайлюка до смерті - під нігтями жертви знайшли біоматеріал цього чоловіка. У цій справі суд підтримав провидців і визнав чоловіка винним у вбивстві.

До розкриття правоохоронними органами злочинів був причетний і такий відомий телепат як Фольф Мессінг. Зокрема, філолог і літератор Ігнатій Шенфельд стверджує, що в 1943 році виявився разом 
Тєнєшев В., Котис В.

Нетрадиційні способи доказування злочинів, чи $€$ перспектива?

з Мессінгом у камері внутрішньої тюрми НКВД Узбекистану (обидва тоді жили в Ташкенті). Телепата незабаром відпустили, а Шенфельда позбавили волі на 10 років за звинуваченням у шпигунстві. Він передбачає, що Мессінг секретно співпрацював з правоохоронними органами, адже мав змогу читати думки та вивідувати таємниці.

Отже, цей спосіб можна використовувати, при цьому підтверджуючи достовірність отриманої інформації в сукупності з іншими допустимими злочинами.

Висновки. Проаналізувавши усі нетрадиційні способи доведення злочинів, їх наукове обгрунтування та позитивний вплив на отримання доказів у зарубіжних країнах можна стверджувати, що застосування їх в кримінальному процесі є доцільним та підтвердженим. Результати впровадження низки нетрадиційних засобів отримання доказів у зарубіжних країнах вражають, тому, на нашу думку, їх цінність і в Україні також стане визнаною суспільством.

\section{Список використаних джерел}

1. Міжнародний пакт про громадянські i політичні права. URL: https://zakon.rada.gov.ua/laws/ show/995_043/ (дата звернення: 23.03.1976).

2. Кримінальний процесуальний кодекс України: за станом на 17 бер. 2020 р. Відомості Верховної Ради України (ВВР). Київ : Парлам. вид-во, 2013. 88 с.

3. Проєкт Закону про доповнення Кримінального процесуального кодексу України положеннями щодо використання поліграфа. URL: http://w1.c1.rada.gov.ua/pls/zweb2/webproc4_1?pf3511=57349 (дата реєстрації 10 груд. 2015 р).

4. Конституція України : чинне законодавство зі змінами та допов. станом на 11 квіт. 2018 р. відп. за вип. А. В. Паливода. Київ: ПАЛИВОДА, 2018. 76 с.

5. Кримінальний кодекс України : чинне законодавство зі змінами та допов. станом на 25 верес. 2019 р./ відп. за вип. А. В. Паливода. Київ: ПАЛИВОДА, 2019. 264 с.

6. Закон України Про оперативно-розшукову діяльність : прийнятий 18 лют. 1992 року № 22. Відомості Верховної Ради України (ВВР), 1992. 303с.

7. Закон України Про судову експертизу: прийнятий 26 січ. 1994 року№ 28, Відомості Верховної Ради України (ВВР), 1994. 232 с.

8. Постанова Кабінету Міністрів України: від 11 травня 2017 р. № 449, Про затвердження Порядку проведення психофізіологічного дослідження із застосуванням поліграфа у Державному бюро розслідувань. URL: https://www.kmu.gov.ua/npas/250108285 (дата звернення: 11 травн. 2017 p).

9. Експертна Рада ВАП. 2015 р. Методика проведення психофізіологічних досліджень. Київ. Експертна Рада ВАП.

10. Cesare Lombroso. Criminal men (1911) New York, NY: Nebman Company.

11. Волобуєв А. Ф. Про використання поліграфа при розслідуванні злочинів. Криміналістика ХХІ століття: матеріали міжнар. наук.-практ. конф. (Харків, 25-26 листоп. 2010 р.). Х. : Право, 2010. 113 с.

\section{References}

1. Mizhnarodnyi pakt pro gromadianski i politychni prava [Covenant on International and Political Rights] (1976, March 23). Retrieved from: https://zakon.rada.gov.ua/laws/show/995_043/ [in Ukrainian].

2. Kryminalnyi protsesyalnyi kodeks Ukrainy [Criminal Procedure Code of Ukraine] (2013, March 17). Vidomosti Verkhovnoi Rady Ukrainy - Bulletin of Verkhovna Rada of Ukraine. Kyiv: Parlam. vyd-vo [in Ukrainian].

3. Proyekt Zakonu pro dopovneniya Kryminalnogo protsesyalnogo kodeksu Ukrainy polozheniamy schodo vykorystannya poligrapha [Draft Law on Supplementing the Criminal Procedure Code of Ukraine with Regulations on the Use of the Polygraph]. (2015, December 10) Retrieved from: http://w1.c1.rada.gov.ua/pls/ zweb2/webproc4_1?pf3511=57349//[in Ukrainian].

4. Konstytutsiya Ukrainy (2018) [Constitution of Ukraine]. (2018, April 11). Kyiv: vyd-vo PALYVODA [in Ukrainian].

5. Kryminalnyi kodeks Ukraine [Criminal Code Ukraine]. (2019, September 25). Kyiv: vyd-vo PALYVODA [in Ukrainian].

6. Zakon Ukrainy Pro operatyvni-rozshukovu diyalnist [Law of Ukraine On Operational Investigation Activities]. (1992, February 18). Vidomosti Verkhovnoi Rady Ukrainy - Bulletin of Verkhovna Rada of Ukraine. Kyiv: Parlam. vyd-vo [in Ukrainian]. 
Кримінальне право та кримінологія. Кримінально-виконавче право. Кримінальний процес та криміналістика. Судова експертиза. Оперативно-розшукова діяльність. Судоустрій. Прокуратура та адвокатура.

7. Zakon Ukrainy pro sudovu ekspertyzu [Law of Ukraine On Forensic Examination] (1994, January 26). Vidomosti Verkhovnoi Rady Ukrainy - Bulletin of Verkhovna Rada of Ukraine. Kyiv: Parlam. vyd-vo [in Ukrainian].

8. Postanova Kabinetu Ministriv Ukrainy pro zatverdghennia Poriadku provedennia psyhofiziologichnogo doslidghennisz iz zastosyvanniam poligrapha u Derzhavnomu biyro rozsliduvan [Resolution of the Cabinet of Ministers of Ukraine On approval of the Procedure for conducting psychophysiological research with the use of a polygraph at the State Bureau of Investigation] (2017, May 11). Retrieved from: https://www.kmu. gov.ua/npas/250108285 [in Ukrainian].

9. Ekspertna Rada VAP. Metodyka provedennia psyhofiziologichnyh doslidzhen [Methods of psychophysiological research] (2015). Kyiv.VAP Expert Council.

10. Cesare Lombroso. Criminal men (1911) New York, NY: Nebman Company.

11. Volobuiev A.F. (2010) Pro vykorystannia poligrapha pry rozsliduvanni zlochyniv [On the use of polygraph in the investigation of crimes]. Kharkiv: Proceedings of the International Conference.

Стаття надійшла до редакції 20.04.2020. 